\title{
A Comprehensive View of the Epigenetic Landscape Part I: DNA Methylation, Passive and Active DNA Demethylation Pathways and Histone Variants
}

\author{
Anna Sadakierska-Chudy • Richard M. Kostrzewa • \\ Małgorzata Filip
}

Received: 11 August 2014/Revised: 7 October 2014/ Accepted: 16 October 2014/Published online: 2 November 2014 (C) The Author(s) 2014. This article is published with open access at Springerlink.com

\begin{abstract}
In multicellular organisms, all the cells are genetically identical but turn genes on or off at the right time to promote differentiation into specific cell types. The regulation of higher-order chromatin structure is essential for genome-wide reprogramming and for tissue-specific patterns of gene expression. The complexity of the genome is regulated by epigenetic mechanisms, which act at the level of DNA, histones, and nucleosomes. Epigenetic machinery is involved in many biological processes, including genomic imprinting, X-chromosome inactivation, heterochromatin formation, and transcriptional regulation, as well as DNA damage repair. In this review, we summarize the recent understanding of DNA methylation, cytosine derivatives, active and passive demethylation pathways as well as histone variants. DNA methylation is one of the well-characterized epigenetic signaling tools. Cytosine methylation of promoter regions usually represses transcription but methylation in the gene body may have a positive correlation with gene expression. The attachment of a methyl group to cytosine residue in the DNA sequence is catalyzed by enzymes of the DNA methyltransferase
\end{abstract}

\section{A. Sadakierska-Chudy $(\bowtie) \cdot$ M. Filip}

Laboratory of Drug Addiction Pharmacology, Institute of

Pharmacology Polish Academy of Sciences, Smetna Street 12,

31-343 Kraków, Poland

e-mail: annasc@if-pan.krakow.pl

\section{R. M. Kostrzewa}

Department of Biomedical Sciences, Quillen College of Medicine, East Tennessee State University, Johnson City, TN 37614, USA

\section{Filip}

Department of Toxicology, Faculty of Pharmacy, Jagiellonian University, Medical College, Medyczna 9, 30-688 Kraków, Poland family. Recent studies have shown that the Ten-Eleven translocation family enzymes are involved in stepwise oxidation of 5-methylcytosine, creating new cytosine derivatives including 5-hydroxymethylcytosine, 5-formylcytosine, and 5-carboxylcytosine. Additionally, histone variants into nucleosomes create another strategy to regulate the structure and function of chromatin. The replacement of canonical histones with specialized histone variants regulates accessibility of DNA, and thus may affect multiple biological processes, such as replication, transcription, DNA repair, and play a role in various disorders such as cancer.

Keywords Cytosine variants - DNA methylation - DNA methyltransferases - Histone variants - Passive and active demethylation $\cdot$ TET family enzymes

\section{Introduction}

In the last decade, epigenetics has become an important topic of genetic research. The classical definition of epigenetics refers to the mitotically and/or meiotically heritable changes in gene activity that does not involve alterations in DNA sequence. This definition emphasizes the heritability of the cellular phenotype, and therefore, it only includes changes in the germ line that can be passed down from generation to generation and changes in dividing cells that can be transferred to daughter cells. Currently, we know that epigenetic changes can be induced by environmental factors at different times in life and are potentially reversible. In 2007, Brenda Weis proposed the broader term of epigenetics that refers to "the study of regulation of gene activity that is not dependent on gene sequence and includes heritable and non-heritable 
alterations in gene activity and transcriptional potential of a cell" (Brenda Weis at the "Diet, Epigenetic Events, and Cancer Prevention Symposium” on September 27th, 2007, in Washington, D.C./http://prevention.cancer.gov/files/ news-events/100908_epigenetics\%20meeting\%20report\% 20Sept\%202007.pdf).

Epigenetic control operates on three major levels, i.e., on DNA, histones, and nucleosomes. The relationships among these various epigenetic elements are currently being extensively investigated. In this review, data from the literature are analyzed to discuss the significance of DNA methylation and demethylation, cytosine derivatives as well as histone variants in the epigenetic regulation of the genome.

\section{DNA Level}

\section{DNA Methylation}

DNA methylation is a biochemical process crucial for normal development in higher organisms, and it is the most thoroughly studied epigenetic mark. Methylation entails the covalent attachment of a methyl $\left(\mathrm{CH}_{3}\right)$ group to the $\mathrm{C} 5$ position of a cytosine residue, forming 5-methylcytosine (5mC).

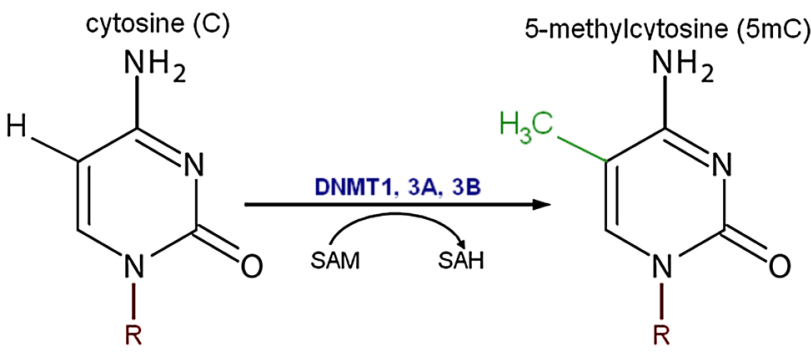

In some organisms, this modification is so frequent that it is denoted as the fifth nucleotide. The methyl group is transferred from $S$-adenosyl-L-methionine (SAM) to cytosine by the DNA methyltransferase (DNMT) family of enzymes: DNMT1, DNMT2, DNMT3A, DNMT3B, and DNMT3L (Jin et al. 2011). DNMT1 preferentially methylates hemimethylated cytosines in $\mathrm{CpG}$ dinucleotide sequences, maintaining the methylation pattern during replication (Probst et al. 2009). In contrast to DNMT1, DNMT3A and 3B prefer unmethylated CpG dinucleotides and perform de novo methylation in early development $(\mathrm{Li}$ 2002). Thus, DNMT1 acts primarily as a maintenance methyltransferase during DNA synthesis, and DNMT3A and DNMT3B act as de novo enzymes in development. A growing body of evidence suggests that DNMT1 may also be necessary for de novo methylation of genomic DNA (Egger et al. 2006) and that DNMT3A and DNMT3B are also responsible for the maintenance of methylation during cell replication (Riggs and Xiong 2004). It is worth noting that DNMT2 displays weak DNA methyltransferase activity but actually functions as an RNA methyltransferase. The DNMT2 enzyme specifically methylates cytosine38 in the anticodon loop of aspartic acid transfer RNA that protects tRNAs from cleavage under stress conditions (Goll et al. 2006; Schaefer et al. 2010).

A recent finding has suggested that DNMT2 might be involved in the mammalian paramutation pathway, by protecting small RNA molecules against endonucleolytic cleavage (Adams and Meehan 2013; Kiani et al. 2013), and thus it might induce heritable epigenetic phenotypes. DNMT3L, although it shares homology with DNMT3A and $3 \mathrm{~B}$, has no catalytic activity. Instead, DNMT3L increases the ability of DNMT3A and B to bind to methyl groups, thus facilitating methylation in vivo (Bird 2002; Jin et al. 2011). Moreover, DNMT3L recognizes nucleosomes with an unmethylated histone $\mathrm{H} 3$ lysine 4 (H3K4) and recruits DNMT3A and DNMT3B to their targets (Saitou et al. 2012). Structural and functional domains of mammalian DNMTs are shown in Fig. 1.

The level of $5 \mathrm{mC}$ affects gene expression, and deregulation of cytosine methylation may play a role in development, cellular differentiation, or disease (Santos-Rebouc and Pimentel 2007; Aguilera et al. 2010; Hackett and Surani 2013). The DNA methylation level can affect transcriptional activities, hypermethylation (a surplus of methyl groups) of promoter regions, and is generally associated with transcriptional silencing, but hypomethylation (a deficit of methyl groups) causes an increased level of gene expression (Crider et al. 2012). Approximately, $2-8 \%$ of the cytosines in the mammalian genome are methylated, mostly in CpG sequences (Zhu 2009; Varriale 2014). In the human genome, $\mathrm{CpG}$ dinucleotides are distributed asymmetrically among GC-rich and -poor DNA regions, and not all $\mathrm{CpG}$ sites are methylated. The pattern of DNA methylation varies in different cell types and is tissue specific. For example, in differentiated mammalian cells, cytosine residues in GC-rich regions (which typically contain more than $50 \%$ GC) are usually methylated. DNA regions that contain a high frequency of $\mathrm{CpG}$ sites are socalled $\mathrm{CpG}$ islands (CGIs) and represent an important feature of the mammalian genome. They are located in promoters, preferentially near the transcription start sites (TSSs) of $>50 \%$ of human genes. CGI methylation is lower at promoters and higher in gene bodies and intergenic regions. CGI-rich promoters are largely free of DNA methylation due to the abundance of GC-rich transcription factor-binding sites (Deaton and Bird 2011). Methylation of DNA cytosine residues at promoter regions usually correlates with a higher order of chromatin state and repression mRNA transcription. However, Niesen et al. 


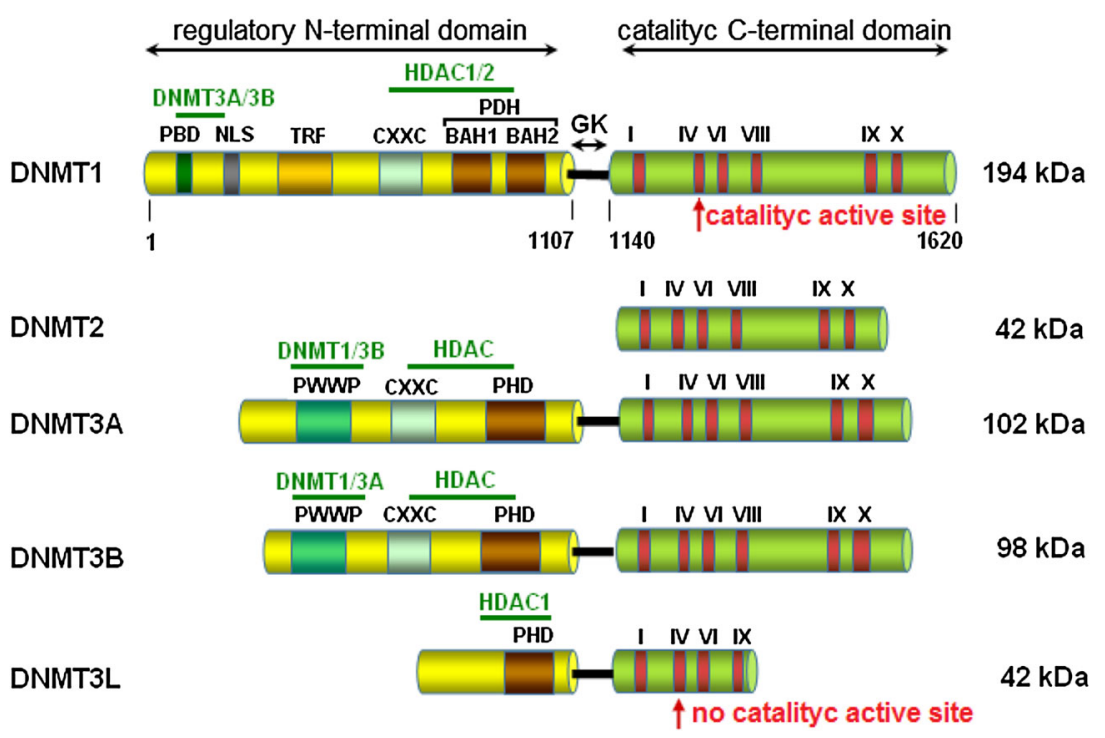

Fig. 1 Schematic structure of mammalian DNMT family members. DNMT1, the first described methyltransferase, preferentially methylates hemimethylated DNA (Robertson 2001). DNMT2 lacks the $\mathrm{N}$-terminal domain, while C-terminal domain contains the full set of sequence motifs but has not been shown to have transmethylase activity (Bestor 2000). DNMT3A and DNMT3B have similar domain arrangements and an equal preference for hemimethylated and unmethylated DNA (Robertson 2001). DNMT3L, being closely related to the catalytic domain of DNMT3A/3B, lacks canonical DNA cytosine-methyltransferase motifs (Bestor 2000). Its N-terminal regulatory domains exhibit little similarity but the catalytic domains of DNMTs are conserved. The N-terminal domain possesses:

(2005) revealed that a sequence-specific DNA-binding protein can facilitate transcriptional activation of methylated promoter. Interestingly, recent findings suggest that in undifferentiated stem cells, cytosines outside of $\mathrm{CpG}$ sites can be methylated as well, and this process is particularly important for the proper regulation of gene expression in embryonic stem cells (ESCs) (Lister et al. 2009). As previously mentioned, gene bodies are highly methylated but the role of methylation remains largely unresolved. Some studies have begun to decipher molecular implications of gene body methylation. For example, methylation in the gene body contributes to the suppression of transcriptional noise (Huh et al. 2011) and might stimulate transcription elongation (Jones 2012). A recent study has suggested that exons are methylated at higher levels than introns and possibly play a role in the regulation of mRNA splicing (Laurent et al. 2010). More details about genomic locations of DNA methylation and its consequence can be found in excellent recent reviews (Estécio and Issa 2011; Moore et al. 2013).

DNA methylation has been considered a stable, persistent and heritable mark; therefore, methyl groups are added but not removed. Recent data have indicated that transcription factors and related proteins not only protect
PBD—proliferating cell nuclear antigen (PCNA) binding domain, NLS - nuclear localization signal, TRF - targeting replication foci, CXXC - cysteine rich, zinc finger DNA-binding motif, $\mathrm{PBH}-$ polybromo homology domain, PWWP-tetrapeptide domain containing proline-tryptophan-tryptophan-proline motif. The N-terminal and $\mathrm{C}$-terminal domains are linked by dinucleotide repeats: $\mathrm{GK}-$ glycine-lysine repeat. The C-terminal domain consists of six most conserved amino acid motifs (motif I and X form SAM binding site, motif IV binds cytosine at the active site). Mapped interaction sites of DNMTs and HDACs (histone deacetylases) are indicated in the above diagrams. The borders of the DNMT1 domains are marked according Song et al. (2011)

sequences from methylation but also initiate active DNA demethylation (Stadler et al. 2011). Both passive demethylation during replication and active demethylation take place in eukaryotic cells. For example, DNA methylation patterns undergo reprogramming during the establishment of primordial germ cells (PGCs) as well as after fertilization (Branco et al. 2011; Saitou et al. 2012). Surprisingly, the establishment of DNA methylation patterns occurs during development and differentiation of the central nervous system, where it has been implicated in synaptic plasticity, learning, and memory. In the human brain, DNA methylation changes are strongly correlated with age (Hernandez et al. 2011). In turn, pathological activation of DNMTs and aberrant $5 \mathrm{mC}$ formation may cause neurodegradation and apoptotic neuronal death (Chestnut et al. 2011; Hernandez and Singleton 2012).

DNA methylation influences gene expression not only by impeding the binding of specific transcription factors but also by recruiting chromatin-modifying proteins. DNA methylation also determines the histone modification patterns and the DNMTs and methyl-CpG-binding domain (MBD) proteins that help to recruit repressor complexes containing histone deacetylases (HDACs) (Fuks et al. 2003). Conversely, interactions between DNMT1, G9a 
(methyltransferase $\mathrm{H} 3 \mathrm{~K} 9$ ), and the replication complex lead to dimethylation of histone $\mathrm{H} 3$ lysine 9 (H3K9me2), a repressive epigenetic mark. Methylated H3K9 is bound by heterochromatin protein 1 (HP1), which interacts directly with DNMT1, resulting in cytosine methylation (Smallwood et al. 2007; Saitou et al. 2012). The interaction of the H3K9 methyltransferases (SUV39H1 and ESET) with DNMT3A and DNMT3B can also cause DNA methylation at H3K9me2 (Fuks et al. 2003). Notably, chromatin organization differs between $\mathrm{CpG}$ and non-CpG promoters. GC-rich DNA is preferentially bound by CXXC domain proteins that can recruit chromatin modifiers, including the CXXC finger protein 1 (Cfp1) subunit of the H3K3me3 methyltransferase complex and KDM2A, an H3K36me2 demethylase (Vavouri and Lehner 2012). In addition to participating in the histone modifications, DNA methylation may influence the incorporation of histone variant H2A.Z into nucleosomes. A growing body of evidence
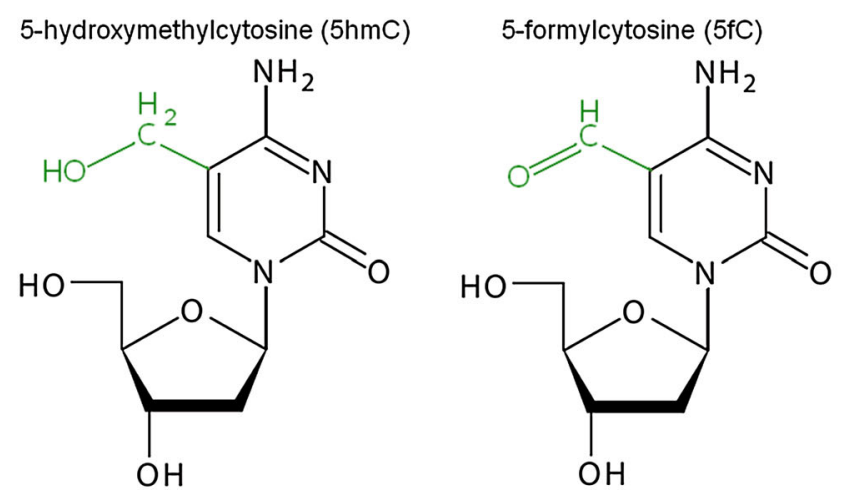

constituents (e.g., folate and bioactive components) may alter genomic and gene-specific DNA methylation levels during embryonic development and adult life (Aguilera et al. 2010; Choi and Friso 2010; McKay and Mathers 2011). Concerning the reversible nature of DNA methylation, it seems to be attractive for epigenetic modulation (Egger et al. 2004; Yang et al. 2010).

\section{Cytosine Variants}

It has long been known that cytosine can exist in one of two functional states, unmethylated or methylated. Moreover, mechanisms of DNA methylation are among the best understood epigenetic phenomena. Recently, several cytosine variants, including 5-hydroxymethylcytosine $(5 \mathrm{hmC})$, 5-formylcytosine (5fC), 5-carboxylcytosine (5caC), and 3-methylcytosine $(3 \mathrm{mC})$, were identified.

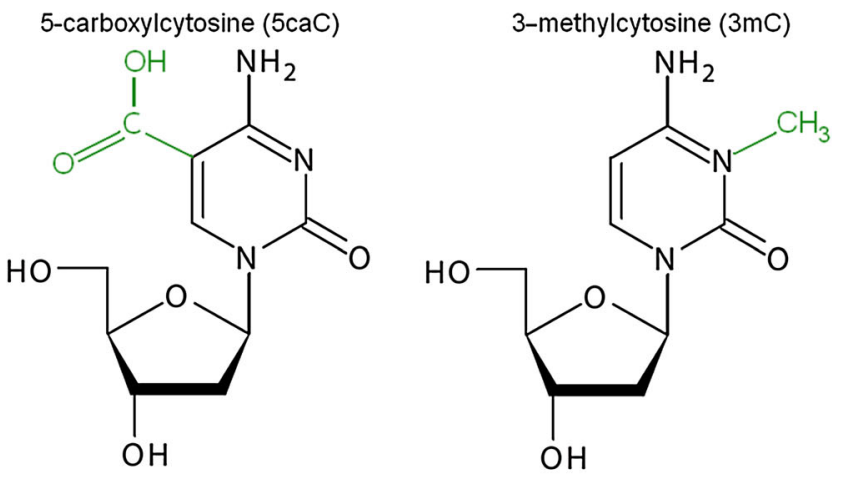

suggests that the H2A.Z is excluded from methylated DNA and the global anticorrelation between DNA methylation and H2A.Z is observed (Conerly et al. 2010; Weber and Henikoff 2014).

Taken together, DNA methylation affects the interaction between the histone and DNA, resulting in either activation or repression of transcription. It is well known that the disruption of methylation patterns can cause many diseases including cancer, autoimmune disease, as well as chromosomal instability, and mental retardation syndromes (Dobrovic 2010; Javierre et al. 2011). In humans, mutations in genes, including DNMTs and methyl-CpG binding proteins (MBPs), could have profound impact on specific DNA methylation patterns leading to epigenetic diseases (Santos-Rebouc and Pimentel 2007). Up to now, more studies have signified that life style and environmental factors, such as nutrient supply, drugs, pollutants, pathogens, sex hormones, radiation, heavy metals, and early stress can modulate DNA methylation (Javierre et al. 2011; Lim and Song 2012). Interestingly, certain dietary

\section{5-Hydroxymethylcytosine $(5 \mathrm{hmC})$}

5-Hydroxymethylcytosine was discovered 60 years ago in T2 bacteriophage (Wyatt and Cohen 1952), and 20 years later Penn et al. found $5 \mathrm{hmC}$ base in mammalian cells (Penn et al. 1972). These early findings could not be replicated in later studies until 2009, when two independent groups showed that $5 \mathrm{hmC}$ exists in mouse Purkinje neurons (Kriaucionis and Heintz 2009) and in ESCs (Tahiliani et al. 2009). Currently, $5 \mathrm{hmC}$ is regarded as the "sixth" base of the genome of higher organisms (Münzel et al. 2010). The levels of $5 \mathrm{hmC}$ in the genome are relatively low and account for $\sim 0.4 \%$ of all cytosines compared to the $\sim 10 \%$ that are $5 \mathrm{mC}$ (Branco et al. 2011). 5hmC constitutes approximately $40 \%$ of the modified cytosines in mouse brain, and the amount increases during maturation in both the hippocampus and the cerebellum (Szulwach et al. 2011). Recently, it has been confirmed that $5 \mathrm{hmC}$ is generated by the Ten-Eleven Translocation (TET) enzymes that are $\mathrm{Fe}(\mathrm{II})$ and $\alpha$-oxoglutarate-dependent dioxygenases. 


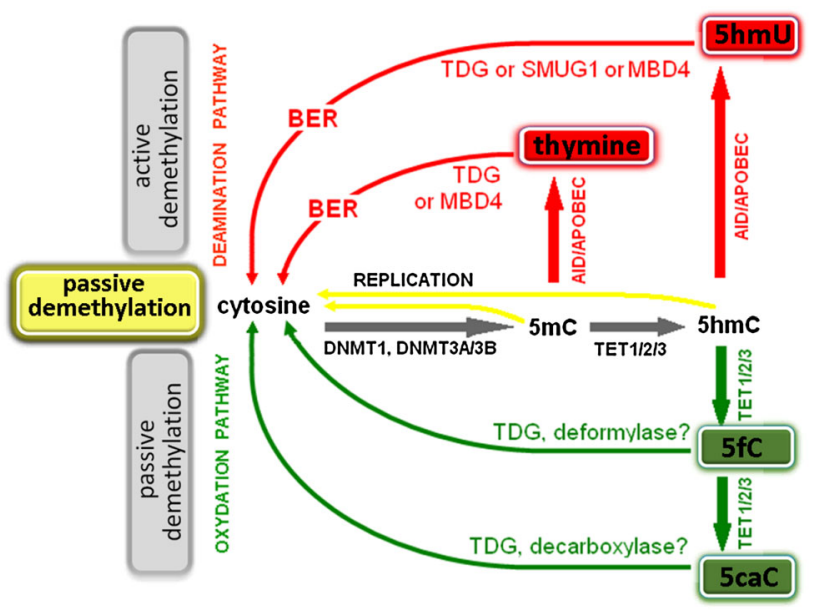

Fig. 2 Passive and active DNA demethylation pathways. Passive DNA demethylation is caused by a reduction in activity or absence of DNMTs (yellow arrows). Active demethylation via oxidation pathway (green arrows): TET enzymes can hydroxylate methylcytosine $(5 \mathrm{mC})$ to form 5-hydroxymethylcytosine $(5 \mathrm{hmC})$; further oxidation produces 5-formylcytosine (5fC) and 5-carboxylcytosine $(5 \mathrm{caC}) .5 \mathrm{fC}$ and $5 \mathrm{caC}$ can be actively removed by the DNA glycosylases. In addition, a putative deformylase may convert $5 \mathrm{fC}$ to $\mathrm{C}$ and decarboxylase convert $5 \mathrm{caC}$ to $\mathrm{C}$. Active demethylation via deamination pathway (red arrows): AID/APOBEC family members can deaminate $5 \mathrm{mC}$ or $5 \mathrm{hmC}$ to form thymidine or 5-hydroxymethyluracil $(5 \mathrm{hmU})$. These intermediates are replaced by cytosine during base excision repair (BER) mediated by the uracil-DNA glycosylase (UDG) family, like TDG or SMUG1 as well as MBD4 (specifically recognize thymine and $5 \mathrm{hmU}$ ). AID activation-induced deaminase, APOBEC apolipoprotein B mRNA-editing enzyme complex, BERbase excision repair, DNMT1/3A/3B-DNA methyltransferase, MBD4-methyl-binding domain protein 4, SMUG1-single-strand specific monofunctional uracil-DNA glycosylase, TET1/2/3-teneleven methylcytosine dioxygenase family, TDG-thymine-DNA glycosylase (Color figure online)

The TET subfamily, including TET1, TET2, and TET3, catalyzes the conversion of $5 \mathrm{mC}-5 \mathrm{hm}$ in vitro and in vivo (Ito et al. 2010; Branco et al. 2011) and may be engaged in the further oxidation of $5 \mathrm{hmC}-5 \mathrm{fC}$ and $5 \mathrm{caC}$ (He et al. 2011; Ito 2011) (Fig. 2). The TET proteins contain iron and oxyglutarate domains as well cysteine-rich regions that are most likely involved in DNA binding (Iyer et al. 2009). Moreover, TET1 and TET3 contain CXXC zinc finger domains, which allow binding to unmethylated, methylated and hydroxymethylated DNA.

Other CXXC-containing proteins, for example DNMT1, almost solely bind to unmethylated DNA; therefore, poor recognition of $5 \mathrm{hmC}$ could lead to passive demethylation (Valinluck and Sowers 2007). The level of $5 \mathrm{hmC}$ in adult tissues is between 0.03 and $0.69 \%$ with the highest levels $(0.4-0.7 \%)$ in the central nervous system (Globisch et al. 2010). The biological role of $5 \mathrm{hmC}$ is still unclear. It has been postulated that $5 \mathrm{hmC}$ could be an intermediate in active DNA demethylation, and it may play an important role in gene regulation (Tahiliani et al. 2009; $\mathrm{Wu}$ and Zhang 2010). It has been observed that $5 \mathrm{hmC}$ is enriched in the body of the active genes and at the TSSs of transcriptionally inactive genes (Song et al. 2010; Wu et al. 2011a). In vitro analysis revealed that $5 \mathrm{hmC}$ in the gene body prevents the binding of MBD proteins, which act as transcriptional repressors (Valinluck et al. 2004; Jin et al. 2010). The level of $5 \mathrm{hmC}$ in the gene body might modify the accessibility of chromatin to the transcriptional machinery. Nestor et al. have demonstrated that $5 \mathrm{hmC}$ patterns are tissue specific. The global content of $5 \mathrm{hmC}$ varies markedly between tissues and does not correlate with global $5 \mathrm{mC}$ levels (Nestor et al. 2012). Chen et al. (2012) have demonstrated that aging increases both globaland locus-specific $5 \mathrm{hmC}$ content in the mouse hippocampus.

It is possible that $5 \mathrm{hmC}$ initiates the pathway of passive or active DNA demethylation by excluding DNMT1 and the MBD proteins from methylating cytosine, and it may recruit other unknown $5 \mathrm{hmC}$-specific effector proteins (Stroud et al. 2011). Recent in vitro studies have revealed that TET proteins could contribute to the removal of methylated cytosine (He et al. 2011; Ito et al. 2011; Matarese et al. 2011). This enzyme family has the capacity to oxidize $5 \mathrm{mC}$ not only to $5 \mathrm{hmC}$ but also to 5 -formylcytosine and 5-carboxylcytosine. Other researchers have shown that thymine-DNA glycosylase (TDG) belonging to the uracil-DNA glycosylase (UDG) superfamily can recognize and excise $5 \mathrm{fC}$ and $5 \mathrm{caC}$; thus, the base excision repair (BER) system could be a trigger (Ooi and Bestor 2008; He et al. 2011; Matarese et al. 2011). The crystal structure of human TDG revealed a binding pocket that can accommodate $5 \mathrm{caC}$ which facilitates its cleavage (Zhang et al. 2012; Kohli and Zhang 2013). Furthermore, TDG can remove $\mathrm{T}: \mathrm{G}$ or hmU:G mismatches generated by enzymatic deamination of $5 \mathrm{mC}$ to thymine and $5 \mathrm{hmC}$ to 5-hydroxymethyluracil (5hmU) (Shen et al. 2014). In addition, alternative UDG glycosylases including methylCpG-binding domain protein 4 (MBD4) and single-strandselective monofunctional uracil-DNA glycosylase 1 (SMUG1) can be involved in active DNA demethylation pathway (Shen et al. 2014). Recent studies have reported that the hydroxylation of $5 \mathrm{mC}$ mediated by the Tet 1 protein promotes active DNA demethylation in the adult brain by deaminating cytosine residue to uracil by the activationinduced deaminase (AID)/apolipoprotein B mRNA-editing enzyme complex (APOBEC) family, and then deaminated cytosine residue is excised by DNA glycosylases and repaired by the BER pathway (Guo et al. 2011). Potential mechanisms responsible for passive and active demethylation are presented in Fig. 2. 


\section{5-Formylcytosine ( $5 f C)$}

5-Formylcytosine is one of the DNA base variants produced by oxidation of $5 \mathrm{hmc}$ by the TET family of enzymes (Ito et al. 2011). Thin layer chromatography and tandem liquid chromatography-mass spectrometry has revealed $5 \mathrm{fC}$ in mouse ESCs and in brain cortex (Raiber et al. 2012). The levels of $5 \mathrm{fC}$ are estimated to be from 0.02 to $0.002 \%$ of the genomic DNA of ES cells and are 10- to 100-fold lower than the levels of $5 \mathrm{hmC}$ (Ito et al. 2011; Pfaffeneder et al. 2011). These levels seem reasonable because TET1 and TET2 are highly expressed and most likely play roles in DNA methylation reprogramming and cell differentiation (Koh et al. 2011). Indeed, during differentiation, levels of $5 \mathrm{fC}$ decrease, suggesting its participation in development and germ cell programming (Pfaffeneder et al. 2011). A recent study has reported that CGI promoters were more enriched in $5 \mathrm{fC}$ levels than in $5 \mathrm{hmC}$ or $5 \mathrm{mC}$ levels, which correlated with active gene expression. Moreover, TDG was shown to be actively involved in the removal of $5 \mathrm{fC}$ marks in CGIs, exons, and promoter regions (Raiber et al. 2012). Therefore, 5fC excision may help to establish correct methylation patterns during cell-specific developmental programs. Surprisingly, 5fC-enriched promoter regions overlap with $\mathrm{H} 3 \mathrm{~K} 4 \mathrm{me} 3$, suggesting cross-talk between these marks in transcriptionally active genes.

\section{5-Carboxylcytosine (5caC)}

5-Carboxylcytosine is one of the intermediates in active DNA demethylation and is produced by TET-mediated enzymatic oxidation from $5 \mathrm{fC}$. The TET3 protein is most likely responsible for this conversion (Gu et al. 2011). To date, $5 \mathrm{caC}$ has been found in ESCs and in mouse preimplantation embryos (Inoue et al. 2011; He et al. 2011). Alioui and co-workers have shown that $5 \mathrm{caC}$ is detectable in the somatic cells of amphibian ovaries and is primarily localized to gene-rich euchromatic regions similar to $5 \mathrm{hmC}$ (Alioui et al. 2012). This study also demonstrated that TDG glycosylase can initiate the BER pathway and cleave $5 \mathrm{caC}$ both in vitro and in vivo, but the MBD4 enzyme exhibited no activity toward $5 \mathrm{caC}$. Interestingly, $5 \mathrm{caC}$ levels increased when TDG was depleted in mouse ES cells; thus, TDG is most likely not the only enzyme capable of processing $5 \mathrm{caC}$ (He et al. 2011). It is not known whether TDG is able to recognize and excise $5 \mathrm{caC}$ from duplex DNA and whether additional enzymes might be engaged in the conversion of $5 \mathrm{caC}$ in mammalian cells.

\section{3-Methylcytosine $(3 m C)$}

3-Methylcytosine is a DNA adduct created by spontaneous exposure to endogenous or environmental alkylating agents, leading to cytotoxicity and carcinogenesis. This mutagenic lesion can be directly repaired with the participation of the $\mathrm{ABH} 3$ or $\mathrm{ABH} 2 \mathrm{DNA}$ dioxygenases through the BER pathway in humans, or it can be dealkylated by AlkB in bacteria (Koivisto et al. 2004; Yi et al. 2012). Biochemical experiments indicate that ALKBH2 prefers double-stranded DNA (dsDNA) substrates, while ALKBH3 prefers single-stranded DNA (ssDNA) substrates, which are generated by the activating signal cointegrator complex (ASCC) (Dango et al. 2011; Yi et al. 2012). Dango et al. (2011) demonstrated that loss of ALKBH3 or ASCC3 significantly reduced cell proliferation in vitro and in vivo in xenograft models. Concurrently, the accumulation of endogenous $3 \mathrm{meC}$ in genomic DNA was observed. Additionally, ALKBH2 has been shown to play an efficient role in pediatric brain tumors during chemotherapy treatment, and the combination of an ALKBH2 knockdown and cisplatin chemotherapy seems to improve the efficacy of treatment (Cetica et al. 2009; Wu et al. 2011b). Taken together, these findings indicate an important role for alkylation repair in removing environmentally induced DNA lesions as well as in maintaining genome integrity and stability.

\section{Histone Variants}

Histones are small, basic, and highly conserved proteins that serve as structural scaffolds for DNA packaging (Cooper 2000). A DNA molecule ( $\sim 147 \mathrm{bp}$ in length) wrapped around the octamer of a histone (two dimers of $\mathrm{H} 2 \mathrm{~A}-\mathrm{H} 2 \mathrm{~B}$ and a heterotetramer $\left.(\mathrm{H} 3-\mathrm{H} 4)_{2}\right)$ constitutes a nucleosome, the fundamental repeating unit of eukaryotic chromatin (Cooper 2000). Histone H1 binds to linker DNA ( $\sim 50 \mathrm{bp}$ ) between nucleosomes, forming a macromolecular structure to help in further compaction of genomic DNA (Sancho et al. 2008). Histone proteins have a tripartite structure consisting of a central globular domain flanked by N- and C-terminal parts (Fig. 3). The unstructured tail located at the $\mathrm{N}$-terminal portion protrudes away from the nucleosome and, therefore, is prone to a variety of post-translational modifications (PTMs) (Kouzarides 2007). The highly conserved globular domain, termed a helix-turn-helix, contains three $\alpha$-helices separated by loop regions and is involved in histone-histone and histoneDNA interactions (Luger 2001). The C-terminal domains of all histones except histone $\mathrm{H} 1$ and $\mathrm{H} 2 \mathrm{~A}$ are relatively short (Vogler et al. 2010).

Histone tails have many positively charged amino acids (especially lysine and arginine), which facilitate their binding to the negatively charged DNA molecule and intranucleosomal interaction (Hansen 2002). The N-terminal histone tails have been studied extensively, but little is 


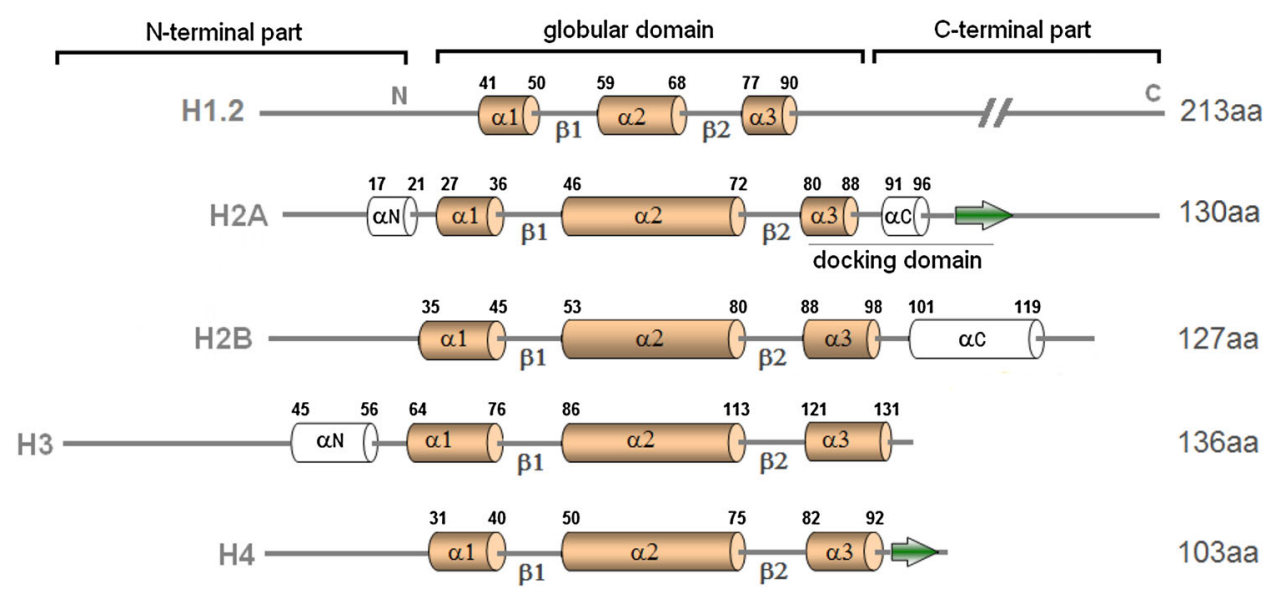

Fig. 3 Schematic structure of the five histone proteins. The N-terminal part is flexible and positively charged and protrudes from the nucleosome. Two short helices, $\alpha-1$ and $\alpha-2$ have a length of 10-14 amino acid residues; central $\alpha-2$ helix comprises $\sim 28$ amino acid residues (Luger 2001). The H2A-docking domain spans amino acids 82-119 and is implicated in both structural and functional properties of the nucleosome (Shukla et al. 2011). It stabilizes the wrapping of one helical turn of DNA around the histone octamer (Shukla et al. 2011) and the binding of $\mathrm{H} 2 \mathrm{~A}-\mathrm{H} 2 \mathrm{~B}$ dimers to $(\mathrm{H} 3-\mathrm{H} 4)_{2}$ tetramers (Bönisch and Hake 2012). In addition, the H2A C-terminus has also been found to be crucial for binding of the linker histone $\mathrm{H} 1$ to nucleosome (Vogler et al. 2010). $\alpha$ helices and $\beta$ strands of the histone fold extensions are shown as open boxes and arrows, respectively
Table 1 Variants of histone $\mathrm{H} 1$ in humans

${ }^{\text {a }}$ Gene expressed in a replication-dependent manner

${ }^{\mathrm{b}}$ Gene expressed in a replication-independent manner

\begin{tabular}{|c|c|c|c|c|}
\hline Variants & $\begin{array}{l}\text { Name of } \\
\text { genes }\end{array}$ & $\begin{array}{l}\text { Genomic } \\
\text { location } \\
(\text { Ensembl) }\end{array}$ & $\begin{array}{l}\text { Protein length } \\
\text { (aa) (Swiss- } \\
\text { Prot) }\end{array}$ & Function (reference) \\
\hline $\mathrm{H} 1.0^{\mathrm{b}}$ & $\mathrm{H} 1 \mathrm{~F} 0$ & $22 \mathrm{q} 13.1$ & 194 & $\begin{array}{l}\text { Nucleosome spacing and chromatin } \\
\text { compaction }\end{array}$ \\
\hline $\mathrm{H} 1.1^{\mathrm{a}}$ & HIST1H1A & $6 \mathrm{p} 22.2$ & 215 & Linker histones inhibit sliding of histone \\
\hline $\mathrm{H} 1.2^{\mathrm{a}}$ & HIST1H1C & $6 \mathrm{p} 22.2$ & 213 & $\begin{array}{l}\text { octamers, and it is postulated that they can } \\
\text { inhibit chromatin remodeling (Clausell } \\
\text { et al. 2009) }\end{array}$ \\
\hline $\mathrm{H} 1.3^{\mathrm{a}}$ & HIST1H1D & $6 \mathrm{p} 22.2$ & 221 & \multirow{8}{*}{$\begin{array}{l}\text { However, a recent study suggested that H1.2- } \\
\text { H1.5 are depleted from active promoters } \\
\text { and gene regulatory elements but enriched } \\
\text { at regions carrying repressive histone marks } \\
\text { (Izzo et al. 2013). H1 binding might be } \\
\text { more sensitive to initiation of transcription } \\
\text { than to transcriptional elongation (Izzo } \\
\text { et al. 2013). Linker histones may operate in } \\
\text { conjunction with a 'network' of other } \\
\text { chromatin-binding proteins so as to define } \\
\text { permissive (euchromatin) and repressive } \\
\text { (heterochromatin) DNA domains (Ausio } \\
\text { 2006). }\end{array}$} \\
\hline $\mathrm{H} 1.4^{\mathrm{a}}$ & HIST1H1E & $6 \mathrm{p} 22.2$ & 219 & \\
\hline $\mathrm{H} 1.5^{\mathrm{a}}$ & HIST1H1B & $6 \mathrm{p} 22.1$ & 226 & \\
\hline $\mathrm{H} 1 \mathrm{x}^{\mathrm{b}}$ & H1FX & $3 \mathrm{q} 21.3$ & 213 & \\
\hline H1oo & H1FOO & $3 q 22.1$ & 346 & \\
\hline $\mathrm{H} 1 \mathrm{t}$ & HIST1H1T & $6 \mathrm{p} 22.2$ & 207 & \\
\hline $\begin{array}{l}\text { Testis- } \\
\text { specific H1 }\end{array}$ & H1FNT & $12 q 13.11$ & 255 & \\
\hline $\begin{array}{l}\text { Spermatid- } \\
\text { specific } \mathrm{H} 1\end{array}$ & HILS1 & $17 \mathrm{q} 21.33$ & 231 & \\
\hline
\end{tabular}

known about the function of the C-terminal part. Vogler et al. have shown that the $\mathrm{H} 2 \mathrm{~A} \mathrm{C}$-terminal tail plays a pivotal role in regulating chromatin structure and dynamics (Vogler et al. 2010). These experiments revealed that the $\mathrm{H} 2 \mathrm{~A}$ C-terminus is required for efficient nucleosome translocation by chromatin remodelers and acts as a novel recognition module for linker histone $\mathrm{H} 1$ (Vogler et al. 2010). It appears that the H2A C-terminal tail has a dual function. On the one hand, it provides stabilization of the nucleosomal core particle, and on the other hand, it participates in interactions with proteins that control chromatin dynamics and conformation.

There are highly similar forms of histones termed 'histone variants'. It has been estimated that approximately 937 different variants of linker and core histones exist in various species. In humans, 57 histone variants are encoded 
Table 2 Variants of histone H2A in humans

\begin{tabular}{|c|c|c|c|c|}
\hline Variants & Name of genes & $\begin{array}{l}\text { Genomic } \\
\text { location } \\
\text { (Ensembl) }\end{array}$ & $\begin{array}{l}\text { Protein length } \\
\text { (aa) (Swiss-Prot) }\end{array}$ & Function (reference) \\
\hline H2A type 1 & $\begin{array}{l}\text { HIST1H2AI } \\
\text { HIST1H2AK } \\
\text { HIST1H2AL } \\
\text { HIST1H2AM } \\
\text { HIST1H2AG }\end{array}$ & $6 \mathrm{p} 22.1$ & 130 & \multirow[t]{10}{*}{ Stabilization of the histone core octamer (Ausio 2006) } \\
\hline $\mathrm{H} 2 \mathrm{~A} 1$ type $1-\mathrm{A}$ & HIST1H2AA & $6 \mathrm{p} 22.2$ & 131 & \\
\hline H2A type1-B/E & $\begin{array}{l}\text { HIST1H2AE } \\
\text { HIST1H2AB }\end{array}$ & $6 \mathrm{p} 22.2$ & 130 & \\
\hline H2A type $1-\mathrm{C}$ & HIST1H2AC & $6 \mathrm{p} 22.2$ & 130 & \\
\hline H2A type $1-\mathrm{D}$ & HIST1H2AD & $6 \mathrm{p} 22.2$ & 130 & \\
\hline H2A type $1-\mathrm{H}$ & HIST1H2AH & $6 \mathrm{p} 22.1$ & 128 & \\
\hline H2A type $1-\mathrm{J}$ & HIST1H2A & $6 \mathrm{p} 22.1$ & 128 & \\
\hline H2A type $2-\mathrm{A}$ & $\begin{array}{l}\text { HIST2H2AA4 } \\
\text { HIST2H2AA4 }\end{array}$ & $1 \mathrm{q} 21.2$ & 130 & \\
\hline H2A type $2-B$ & HIST2H2AB & $1 \mathrm{q} 21.2$ & 130 & \\
\hline $\mathrm{H} 2 \mathrm{~A}$ type $2-\mathrm{C}$ & HIST2H2AC & $1 \mathrm{q} 21.2$ & 129 & \\
\hline H2A type 3 & HIST3H2A & $1 \mathrm{q} 42.13$ & 130 & Unknown function \\
\hline H2A-Bbd type 1 & H2AFB1 & $\mathrm{Xq} 28$ & 115 & Transcription activation (Tolstorukov et al. 2012) \\
\hline H2A-Bbd type $2 / 3$ & $\begin{array}{l}\mathrm{H} 2 \mathrm{AFB} 2 \\
\mathrm{H} 2 \mathrm{AFB} 3\end{array}$ & $\mathrm{Xq} 28$ & 115 & Transcription activation (Tolstorukov et al. 2012) \\
\hline H2A.J & $\mathrm{H} 2 \mathrm{AFJ}$ & $12 \mathrm{p} 12.3$ & 129 & unknown function \\
\hline H2A.X & $\mathrm{H} 2 \mathrm{AFX}$ & $11 \mathrm{q} 23.3$ & 143 & $\begin{array}{l}\text { Genome integrity: DNA repair regulation (Pusarla and } \\
\text { Bhargava 2005) }\end{array}$ \\
\hline H2A.Z.1 & H2AFZ & $4 q 23$ & 128 & \multirow{2}{*}{$\begin{array}{l}\text { Maintenance of heterochromatin, transcription } \\
\text { repression and activation (Fan et al. 2004; Guillemette } \\
\text { et al. 2005; Raisner et al. 2005) }\end{array}$} \\
\hline H2A.Z.2 & $\mathrm{H} 2 \mathrm{AFV}$ & $7 \mathrm{p} 13$ & 128 & \\
\hline macroH2A.1 & H2AFY & $5 q 31.1$ & 372 & $\begin{array}{l}\text { Silencing: enriched in inactivated chromosome X } \\
\text { (Pusarla and Bhargava 2005) }\end{array}$ \\
\hline macroH2A.2 & $\mathrm{H} 2 \mathrm{AFY} 2$ & $10 q 22.1$ & 372 & $\begin{array}{l}\text { Silencing: enriched in inactive X-chromosome } \\
\text { chromatin and in senescence-associated } \\
\text { heterochromatin (Pusarla and Bhargava 2005) }\end{array}$ \\
\hline
\end{tabular}

by 94 genes, the majority of them being present in four clusters: cluster 1 on chromosome 6 (6p22), cluster 2 on chromosome 1 (1p21), cluster 3 on chromosome 1 (1q42), and cluster 4 on chromosome 12 (12p12-13). The incorporation of specific histone variants into nucleosomes has significant impacts on gene expression, heterochromatization, and the formation of specialized regions of the chromatin (Kamakaka and Biggins 2005; Pusarla and Bhargava 2005). The histone variants have recently emerged as important factors in regulating chromatin states and also DNA repair in response to genotoxic treatments (Malik and Henikoff 2003). Moreover, it is likely that histone variants, as potential drivers of cancer initiation and/or progression, thus may be utilized as prognostic indicators of cancer (Vardabasso et al. 2014).
Histone H1

Histone H1 proteins consist of 194-346 amino acid residues, depending on the variant. Approximately 126 different members of the $\mathrm{H} 1$ family have been reported from diverse species thus far (http://www.actrec.gov.in/histome/ ). Eleven variants of histone $\mathrm{H} 1$ have been described in humans; these are coded by a single gene that exhibits either replication-dependent or replication-independent expression (Table 1). Three of the variants are testis-specific (i.e., HIST1H1T, H1FNT, and HILS1), one of them is oocyte-specific (H1foo), and the others are somatic variants. Linker histone $\mathrm{H} 1$ is involved in chromatin compaction and plays a role in the formation of higher-order chromatin structures (Millán-Ariño et al. 2014). The 
Table 3 Variants of histone H2B in humans

\begin{tabular}{|c|c|c|c|c|}
\hline Variants & Name of genes & $\begin{array}{l}\text { Genomic } \\
\text { location } \\
\text { (Ensembl) }\end{array}$ & $\begin{array}{l}\text { Protein length } \\
\text { (aa) (Swiss-Prot) }\end{array}$ & Function (references) \\
\hline H2B type 1-A & HIST1H2BA & $6 \mathrm{p} 22.2$ & 127 & \multirow{23}{*}{$\begin{array}{l}\text { Specific role of H2B variants is poorly understood. It } \\
\text { is probable that they specialize in chromatin } \\
\text { compaction and transcription repression, } \\
\text { particularly during gametogenesis (Kamakaka and } \\
\text { Biggins 2005) }\end{array}$} \\
\hline H2B type $1-B$ & HIST1H2BB & $6 \mathrm{p} 22.2$ & 126 & \\
\hline \multirow[t]{5}{*}{ H2B type $1-\mathrm{c} / \mathrm{E} / \mathrm{F} / \mathrm{G} / \mathrm{I}$} & HIST1H2BG & $6 \mathrm{p} 22.2$ & 126 & \\
\hline & HIST1H2BF & & & \\
\hline & HIST1H2BE & & & \\
\hline & HIST1H2BI & & & \\
\hline & HIST1H2BC & & & \\
\hline H2B type 1-D & HIST1H2BD & $6 \mathrm{p} 22.2$ & 126 & \\
\hline H2B type $1-\mathrm{H}$ & HIST1H2BH & $6 \mathrm{p} 22.2$ & 126 & \\
\hline H2B type 1-J & HIST1H2BJ & $6 \mathrm{p} 22.1$ & 126 & \\
\hline H2B type $1-\mathrm{K}$ & HIST1H2BK & $6 \mathrm{p} 22.1$ & 126 & \\
\hline H2B type $1-\mathrm{L}$ & HIST1H2BK & $6 \mathrm{p} 22.1$ & 126 & \\
\hline H2B type 1-M & HIST1H2BM & $6 \mathrm{p} 22.1$ & 126 & \\
\hline H2B type $1-\mathrm{N}$ & HIST1H2BN & $6 \mathrm{p} 22.1$ & 126 & \\
\hline H2B type $1-\mathrm{O}$ & HIST1H2BN & $6 \mathrm{p} 22.1$ & 126 & \\
\hline H2B type 2-E & HIST2H2BE & $1 \mathrm{q} 21.2$ & 126 & \\
\hline H2B type $2-\mathrm{F}$ & HIST2H2BF & $1 \mathrm{q} 21.2$ & 126 & \\
\hline H2B type $3-\mathrm{B}$ & HIST3H2BB & $1 q 42.13$ & 126 & \\
\hline H2B type F-M & H2BFM & $\mathrm{Xq} 22.2$ & 257 & \\
\hline H2B type F-S & $\mathrm{H} 2 \mathrm{BFS}$ & $21 \mathrm{q} 22.3$ & 126 & \\
\hline H2B type W-T & H2BFWT & $\mathrm{Xq} 22.2$ & 175 & \\
\hline putative $\mathrm{H} 2 \mathrm{~B}$ type $2-\mathrm{C}$ & HIST2H2BC & $1 \mathrm{q} 21.2$ & 193 & \\
\hline putative $\mathrm{H} 2 \mathrm{~B}$ type $2-\mathrm{D}$ & HIST2H2BD & $1 \mathrm{q} 21.2$ & 164 & \\
\hline
\end{tabular}

specific role of histone $\mathrm{H} 1$ variants is still far from clear, and genomic distribution of $\mathrm{H} 1$ is challenging due to the lack of variant-specific antibodies (Izzo et al. 2013).

\section{Histone $\mathrm{H} 2 \mathrm{~A}$}

Histone $\mathrm{H} 2 \mathrm{~A}$ proteins are composed of $\sim 130$ amino acid residues, but atypical variants (macroH2As, H2A.X and H2A-Bbd) differ in size. Approximately 265 different members of histone $\mathrm{H} 2 \mathrm{~A}$ were identified from a variety of species (http://www.actrec.gov.in/histome/). In humans, nineteen variants of histone $\mathrm{H} 2 \mathrm{~A}$ encoded by 26 genes were reported (Table 2).

\section{Histone $\mathrm{H} 2 \mathrm{~B}$}

Except for four variants, the variants of histone H2B contain 126 amino acid residues. The histone H2B family contains 214 different members described from diverse species (http://www.actrec.gov.in/histome/). Histone H2B forms a dimer with histone $\mathrm{H} 2 \mathrm{~A}$ in nucleosome cores. Histone $\mathrm{H} 2 \mathrm{~B}$ has 19 variants encoded by 23 genes in humans, the majority of which are assembled in cluster 1 (i.e., 6p22.1-22.2) (Table 3). There are relatively few PTMs identified among the amino acid residues of histone H2B compared to other core histones.

Histone $\mathrm{H} 3$

Histone $\mathrm{H} 3$ consists of $\sim 136$ amino acid residues; only the centromere protein A (CENP-A) is a longer variant. The histone H3 family contains 216 different members characterized from various species (http://www.actrec.gov.in/ histome/). In humans, 20 genes encode 8 variants of histone $\mathrm{H} 3$, most of which are clustered on chromosome 6 (Table 4). Histone H3 is the most extensively post-translationally modified of the five histones.

\section{Histone $\mathrm{H} 4$}

Histone $\mathrm{H} 4$ contains only 103 amino acid residues and forms a heterotetramer $(\mathrm{H} 3-\mathrm{H} 4)_{2}$ with histone $\mathrm{H} 3$. The histone $\mathrm{H} 4$ family consists of 116 members reported from different organisms (http://www.actrec.gov.in/histome/). Interestingly, humans have a single histone $\mathrm{H} 4$ protein encoded by 14 genes, eleven of which are clustered on chromosome 6 (Table 5). 
Table 4 Variants of histone H3 in humans

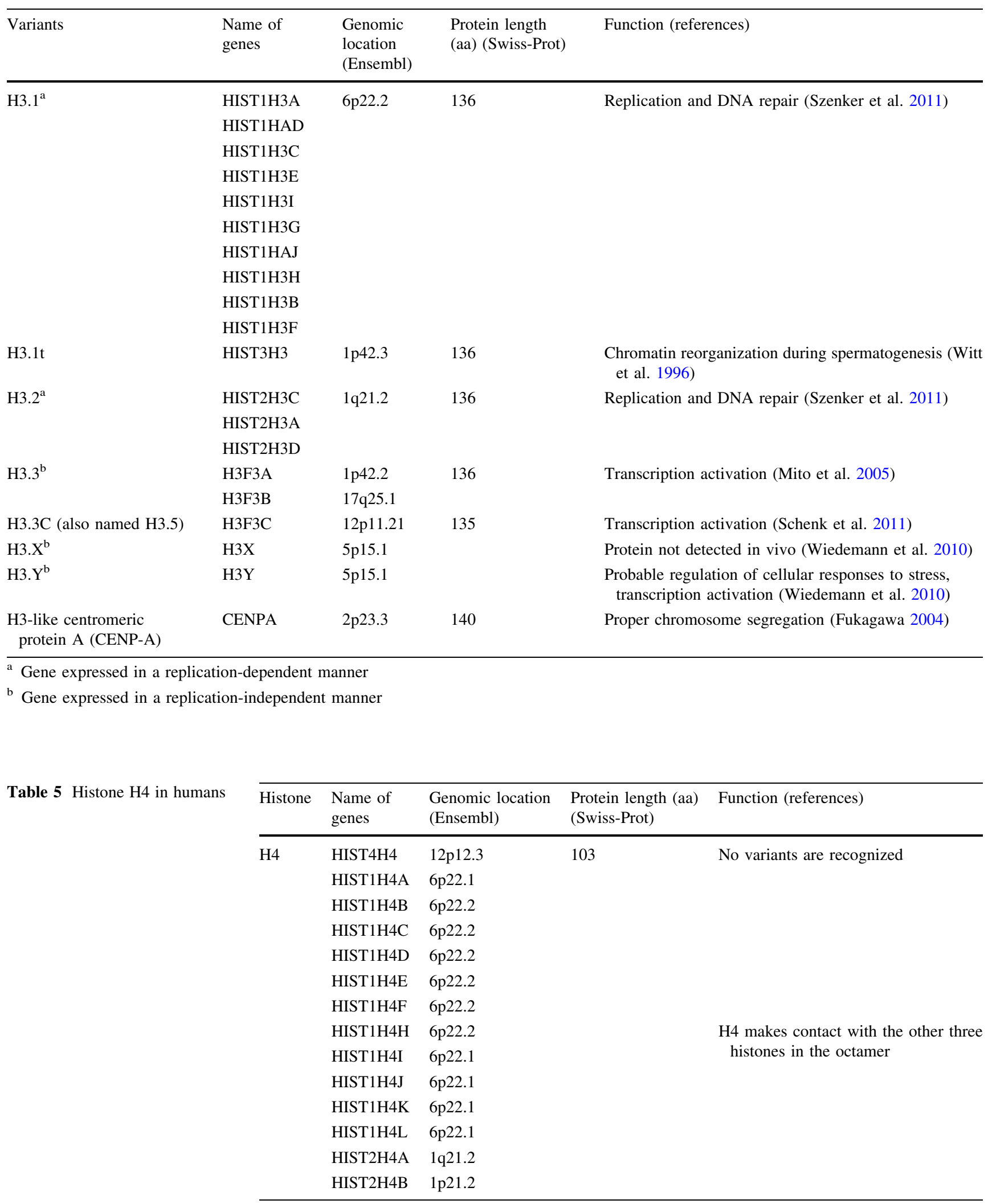




\section{Conclusions}

DNA methylation is considered to be a relatively stable epigenetic modification. Recent genome-wide analyses of the DNA methylation in mammalian cells suggest that some enzymes are capable of erasing or modifying existing methylation patterns. Although DNA cytosine methylation is well-characterized, little is known about the role of cytosine derivatives in gene expression regulation. In the future, high-resolution sequencing technologies should enable creation of quantitative maps of $5 \mathrm{hmC}, 5 \mathrm{fC}$, and $5 \mathrm{caC}$ in different cell types. Understanding the dynamics of these modifications can help to explain their role in physiological or pathological conditions. Interestingly, due to subtle sequence divergences, incorporation of histone variants may influence the stability of nucleosome and change the potential of specific histone modifications. Histone variant composition is a key player in shaping chromatin structure; this also should be considered as one of the epigenetic regulation elements. It is well known that epigenetic disturbance may lead to different phenotypes and monogenic or complex diseases as well as oncogenic transformation. We strongly believe that rapidly growing understanding of epigenetic phenomena could bring a breakthrough in the diagnosis and treatment of many disorders. Moreover, better knowledge about the epigenetic etiology of the diseases provides an opportunity to develop innovative new epigenetic drugs.

Acknowledgments This work was supported by the Grant from the National Science Centre no. 2012/06/A/NZ3/00022 and the statutory funds of the Laboratory of Drug Addiction Pharmacology, Institute of Pharmacology PAS.

Conflict of interest The authors declare that they have no conflict of interests.

Open Access This article is distributed under the terms of the Creative Commons Attribution License which permits any use, distribution, and reproduction in any medium, provided the original author(s) and the source are credited.

\section{References}

Adams IR, Meehan RR (2013) From paramutation to paradigm. PLOS Genet 9(5):e1003537

Aguilera O, Fernández AF, Muñoz A, Fraga MF (2010) Epigenetics and environment: a complex relationship. J Appl Physiol 109:243-251

Alioui A, Wheldon LM, Abakir A, Ferjentsik Z, Johnson AD, Ruzov A (2012) 5-carboxylcytosine is localized to euchromatic regions in the nuclei of follicular cells in axolotl ovary. Nucleus 3(6):565-569

Ausio J (2006) Histone variants-the structure behind the function. Brief Funct Genom Proteom 5(3):228-243

Bestor TH (2000) The DNA methyltransferase of mammals. Hum Mol Genet 9(16):2395-2402
Bird A (2002) DNA methylation patterns and epigenetic memory. Genes Dev 16:6-21

Bönisch C, Hake SB (2012) Histone H2A variants in nucleosomes and chromatin: more or less stable? Nucleic Acids Res 40(21):10719-10741

Branco MR, Ficz G, Reik W (2011) Uncovering the role of 5-hydroxymethylcytosine in the epigenome. Nat Rev Genet 13(1):7-13

Cetica V, Genitori L, Giunti L, Sanzo M, Bernini G, Massimino M, Sardi I (2009) Pediatric brain tumors: mutations of two dioxygenases (hABH2 and hABH3) that directly repair alkylation damage. J Neurooncol 94(2):195-201

Chen H, Dzitoyeva S, Manev H (2012) Effect of aging on 5-hydroxymethylcytosine in the mouse hippocampus. Restor Neurol Neurosci 30(3):237-245

Chestnut BA, Chang Q, Price A, Lesuisse C, Wong M, Martin LM (2011) Epigenetic regulation of motor neuron cell death through DNA methylation. J Neurosci 31(46):16619-16636

Choi SW, Friso S (2010) Epigenetics: A new bridge between nutrition and health. Adv Nutr 1:8-16

Clausell J, Happel N, Hale TK, Doenecke D, Beato M (2009) Histone H1 subtypes differentially modulate chromatin condensation without preventing ATP-Dependent remodeling by SWI/SNF or NURF. PLoS ONE 4(10):e0007243

Conerly ML, Teves SS, Diolaiti D, Ulrich M, Eisenman RN, Henikoff S (2010) Changes in H2A.Z occupancy and DNA methylation during B-cell lymphomagenesis. Genome Res 20:1383-1390

Cooper GM (2000) The cell: a molecular approach 2nd edn. Chapter 4, the organization of cellular genomes. Sinauer Associates, Sunderland

Crider KS, Yang TP, Berry RJ, Bailey LB (2012) Folate and DNA methylation: a review of molecular mechanisms and the evidence for folate's role. Adv Nutr 3:1-38

Dango S, Mosammaparast N, Sowa ME, Xiong LJ, Wu F, Park K, Rubin M, Gygi S, Harper KW, Shi Y (2011) DNA unwinding by ASCC3 helicase is coupled to ALKBH3-dependent DNA alkylation repair and cancer proliferation. Mol Cell 44(3):373-384

Deaton AM, Bird A (2011) CpG islands and the regulation of transcription. Genes and Dev 25:1010-1022

Dobrovic A (2010) Methods for analysis DNA methylation. In: Coleman WB, Tsongalis GJ (eds) Molecular diagnostics for the clinical laboratorian, 2nd edn. Humana Press, New York, pp 149-160

Egger G, Liang G, Aparicio A, Jones PA (2004) Epigenetics in human disease and prospects for epigenetic therapy. Nature 429(6990):457-463

Egger G, Jeong S, Escobar SG, Cortez CC, Li TW, Saito Y, Yoo CB, Jones PA, Liang G (2006) Identification of DNMT1 (DNA methyltransferase 1) hypomorphs in somatic knockouts suggests an essential role for DNMT1 in cell survival. Proc Natl Acad Sci USA 103(38):14080-14085

Estécio MRH, Issa JPJ (2011) Dissecting DNA hypermethylation in cancer. FEBS Lett 585:2078-2086

Fan JY, Rangasamy D, Luger K, Tremethick DJ (2004) H2AZ alters the nucleosome surface to promote HP1alpha-mediated chromatin fibre folding. Mol Cell 16(4):655-661

Fukagawa T (2004) Centromere DNA proteins and kinetochore assembly in vertebrate cells. Chromosome Res 12(6):557-567

Fuks F, Hurd PJ, Deplus R, Kouzarides T (2003) The DNA methyltransferases associate with HP1 and the SUV39H1 histone methyltransferase. Nucleic Acids Res 31(9):2305-2312

Globisch D, Münzel M, Müller M, Michalakis S, Wagner M, Koch S, Brückl T, Biel M, Carell T (2010) Tissue distribution of 5-hydroxymethylcytosine and search for active demethylation intermediates. PLoS ONE 5(12):e15367 
Goll MG, Kirpekar F, Maggert KA, Yoder JA, Hsieh CL, Zhang X, Golic KG, Jacobsen SE, Bestor TH (2006) Methylation of tRNA Asp by the DNA methyltransferase homolog Dnmt2. Science 311(5759):395-398

Gu TP, Guo F, Yang H, Wu HP, Xu GF, Liu W, Xie ZG, Shi L, He X, Jin S, Iqbal K, Shi YG, Deng Z, Szabò PE, Pfeifer GP, Li J, Xu GL (2011) The role of Tet3 DNA dioxygenase in epigenetic reprogramming by oocytes. Nature 477(7366):606-610

Guillemette B, Bataille AR, Gevry N, Adam M, Blanchette M, Robert F, Gaudreau L (2005) Variant histone H2AZ is globally localized to the promoters of inactive yeast genes and regulates nucleosome positioning. PLoS Biol 3(12): e384

Guo JU, Su Y, Zhong C, Ming GL, Song H (2011) Hydroxylation of 5-methylcytosine by TET1 promotes active DNA demethylation in the adult brain. Cell 145(3):423-434

Hackett JA, Surani MA (2013) DNA methylation dynamics during the mammalian life cycle. Phil Trans R Soc B 368:20110328

Hansen JC (2002) Conformational dynamics of the chromatin fiber in solution: determinants mechanisms and functions. Ann Rev Biophys Biomol Struct 31:361-392

He YF, Li BZ, Li Z, Liu P, Wang Y, Tang Q, Ding J, Jia Y, Chen Z, Li L, Sun Y, Li X, Dai Q, Song CX, Zhang K, He C, Xu GL (2011) Tetmediated formation of 5-carboxylcytosine and its excision by TDG in mammalian DNA. Science 333(6047): 1303-1307

Hernandez DG, Singleton AB (2012) Using DNA methylation to understand biological consequences of genetic variability. Neurodegener Dis 9(2):53-59

Hernandez DG, Nalls MA, Gibbs JR, Arepalli S, van der Brug M, Chong S, Moore M, Longo DL, Cookson MR, Traynor BJ, Singleton AB (2011) Distinct DNA methylation changes highly correlated with chronological age in the human brain. Hum Mol Genet 20(6):1164-1172

Huh I, Zeng J, Park T, Yi SV (2011) DNA methylation and transcriptional noise. Epigenet Chromatin 6:9

Inoue A, Shen L, Dai Q, He C, Zhang Y (2011) Generation and replication-dependent dilution of $5 \mathrm{fC}$ and $5 \mathrm{caC}$ during mouse preimplantation development. Cell Res 21(12):1670-1676

Ito S, D'Alessio AC, Taranova OV, Hong K, Lawrence C, Sowers L, Zhang Y (2010) Role of Tet proteins in $5 \mathrm{mC}$ to $5 \mathrm{hmC}$ conversion ES-cell self-renewal and inner cell mass specification. Nature 466(7310):1129-1133

Ito S, Shen L, Dai Q, Wu SC, Collins LB, Swenberg JA, He C, Zhang Y (2011) Tet proteins can convert 5-methylcytosine to 5-formylcytosine and 5-carboxylcytosine. Science 333(6047):1300-1303

Iyer LM, Tahiliani M, Rao A, Aravind L (2009) Prediction of novel families of enzymes involved in oxidative and other complex modifications of bases in nucleic acids. Cell Cycle 8(11): 1698-1710

Izzo A, Kamieniarz-Gdula K, Ramírez F, Noureen N, Kind J, Manke T, van Steensel B, Schneider R (2013) The genomic landscape of the somatic linker histone subtypes H1.1 to H1.5 in human cells. Cell Rep 3:2142-2154

Javierre BM, Hernando H, Ballestar E (2011) Environmental triggers and epigenetic deregulation in autoimmune disease. Discov Med. 12(67):535-545

Jin SG, Kadam S, Pfeifer GP (2010) Examination of the specificity of DNA methylation profiling techniques towards 5-methylcytosine and 5-hydroxymethylcytosine. Nucleic Acids Res 38(11):e125

Jin B, Li Y, Robertson KD (2011) DNA Methylation: superior or subordinate in the epigenetic hierarchy? Genes Cancer 2(6):607-617

Jones PA (2012) Functions of DNA methylation: islands, start sites, gene bodies and beyond. Nat Rev Genet 13(7):484-492

Kamakaka RT, Biggins S (2005) Histone variants: deviants? Genes Dev 19(3):295-310
Kiani J, Grandjean V, Liebers R, Tuorto F, Ghanbarian H, Lyko F, Cuzin F, Rassoulzadegan M (2013) RNA-mediated epigenetic heredity requires the cytosine methyltransferase Dnmt2. PLOS Gene 9(5):e1003498

Koh KP, Yabuuchi A, Rao S, Huang Y, Cunniff K, Nardone J, Laiho A, Tahiliani M, Sommer CA, Mostoslavsky G, Lahesmaa L, Orkin SH, Rodig SJ, Daley GQ (2011) Rao A Tet1 and Tet2 regulate 5-hydroxymethylcytosine production and cell lineage specification in mouse embryonic stem cells. Cell Stem Cell 8(2):200-213

Kohli RM, Zhang Y (2013) TET enzymes, TDG and dynamics of DNA demethylation. Nature 502(7472):472-479

Koivisto P, Robins P, Lindahl T, Sedgwick B (2004) Demethylation of 3-methylthymine in DNA by bacterial and human DNA dioxygenases. J Biol Chem 279(39):40470-40474

Kouzarides T (2007) Chromatin modifications and their function. Cell 128(4):693-705

Kriaucionis S, Heintz N (2009) The nuclear DNA base 5-hydroxymethylcytosine is present in brain and enriched in Purkinje neurons. Science 324(5929):929-930

Laurent L, Wong E, Li G, Huynh T, Tsirigos A, Ong CT, Low HM, Sung KWK, Rigoutsos I, Loring J, Wei CL (2010) Dynamic changes in the human methylome during differentiation. Genome Res 20(3):320-331

Li E (2002) Chromatin modification and epigenetic reprogramming in mammalian development. Nat Rev Genet 3(9):662-673

Lim U, Song MA (2012) Dietary and lifestyle factors of DNA methylation. Methods Mol Biol 863:359-376

Lister R, Pelizzola M, Dowen RH, Hawkins RD, Hon G, TontiFilippini J, Nery JR, Lee L, Ye Z, Ngo QM, Edsall L, Antosiewicz-Bourget J, Stewart R, Ruotti V, Millar AH, Thomson JA, Ren B, Ecker JR (2009) Human DNA methylomes at base resolution show widespread epigenomic differences. Nature 462:315-322

Luger K (2001) Nucleosomes: structure and function. In: Encyclopedia of life sciences. Nature Publishing Group, New York, pp 1-8

Malik HS, Henikoff S (2003) Phylogenomics of the nucleosome. Nat Struct Biol 10:882-891

Matarese F, Carrillo-de Santa Pau E, Stunnenberg HG (2011) 5-hydroxymethylcytosine: a new kid on the epigenetic block? Mol Syst Biol 7:562

McKay JA, Mathers JC (2011) Diet induced epigenetic changes and their implications for health. Acta Physiol 202:103-118

Millán-Ariño L, Islam ABMMK, Izquierdo-Bouldstridge A, Mayor R, Terme JM, Luque N, Sancho M, López-Bigaq N, Jordan A (2014) Mapping of six somatic linker histone H1 variants in human breast cancer cells uncovers specific features of H1.2. Nucleic Acid Res 42(7):4474-4493

Mito Y, Henikoff JG, Henikoff S (2005) Genome-scale profiling of histone H3.3 replacement patterns. Nat Genet 37:1090-1097

Moore LD, Le T, Fan G (2013) DNA methylation and its basic function. Neuropsychopharmacology Reviews 38:23-38

Münzel M, Globisch D, Brückl T, Wagner M, Welzmiller V, Michalakis S, Müller M, Biel M, Carell T (2010) Quantification of the sixth DNA base hydroxymethylcytosine in the brain. Angew Chem Int Ed Engl 49(31):5375-5377

Nestor CE, Ottaviano R, Reddington J, Sproul D, Reinhardt D, Dunican D, Katz E, Dixon JM, Harrison DJ, Meehan RR (2012) Tissue type is a major modifier of the 5-hydroxymethylcytosine content of human genes. Genome Res 22(3):467-477

Niesen MI, Osborne AR, Yang H, Rastogi S, Chellappan S, Cheng JQ, Boss JM, Blanck G (2005) Activation of a methylated promoter mediated by a sequence-specific DNA-binding protein, RFX. J Biol Chem 280:38914-38922 
Ooi SK, Bestor TH (2008) The colorful history of active DNA demethylation. Cell 133(7):1145-1148

Penn NW, Suwalski R, O'Riley C, Bojanowski K, Yura R (1972) The presence of 5-hydroxymethylcytosine in animal deoxyribonucleic acid. Biochem J 126(4):781-790

Pfaffeneder T, Hackner B, Truss M, Münzel M, Müller M, Deiml CA, Hagemeier C, Carell T (2011) The discovery of 5-formylcytosine in embryonic stem cell. Angew Chem Int Ed Engl 50(31):7146-7150

Probst AV, Dunleavy E, Almouzni G (2009) Epigenetic inheritance during the cell cycle. Nat Rev Mol Cell Biol 10(3):192-206

Pusarla RH, Bhargava P (2005) Histones in functional diversification core histone variants. FEBS J 272(20):5149-5168

Raiber E, Beraldi D, Ficz G, Burgess HE, Branco MR, Murat P, Oxley P, Booth MJ, Reik W, Balasubramanian S (2012) Genome-wide distribution of 5-formylcytosine in embryonic stem cells is associated with transcription and depends on thymine DNA glycosylase. Genome Biol 13(8):R69

Raisner RM, Hartley PD, Meneghini MD, Bao MZ, Liu CL, Schreiber SL, Rando OJ, Madhani HD (2005) Histone variant H2AZ marks

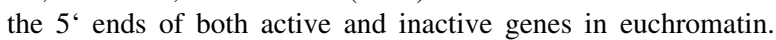
Cell 123(2):233-248

Riggs AD, Xiong Z (2004) Methylation and epigenetic fidelity. Proc Natl Acad Sci USA 101(1):4-5

Robertson KD (2001) DNA methylation methyltransferases and cancer. Oncogene 20(24):3139-3155

Saitou M, Kagiwada S, Kurimoto K (2012) Epigenetic reprogramming in mouse pre-implantation development and primordial germ cells. Development 139(1):15-31

Sancho M, Diani E, Beato M, Jordan A (2008) Depletion of human $\mathrm{H} 1$ variants uncovers specific roles in gene expression and cell growth. PLoS Genet 4(10):e1000227

Santos-Rebouc CB, Pimentel MMG (2007) Implication of abnormal epigenetic patterns for human diseases. Eur J Hum Genet 15:10-17

Schaefer M, Pollex T, Hanna K, Tuorto F, Meusburger M, Helm M, Lyko F (2010) RNA methylation by Dnmt2 protects transfer RNAs against stress-induced cleavage. Genes Dev 24(15):1590-1595

Schenk R, Jenke A, Zilbauer M, Wirth S, Postberg J (2011) H3.5 is a novel hominid-specific histone $\mathrm{H} 3$ variant that is specifically expressed in the seminiferous tubules of human testes. Chromosoma 120(3):275-285

Shen L, Song CX, He C, Zhang Y (2014) Mechanism and function of oxidative reversal of DNA and RNA methylation. Annu Rev Biochem 83:585-614

Shukla MS, Syed SH, Goutte-Gattat D, Richard JL, Montel F, Hamiche A, Travers A, Faivre-Moskalenko C, Bednar J, Hayes JJ, Angelov D, Dimitrov S (2011) The docking domain of histone $\mathrm{H} 2 \mathrm{~A}$ is required for $\mathrm{H} 1$ binding and RSC-mediated nucleosome remodeling. Nucleic Acids Res 39(7):2559-2570

Smallwood A, Estève PO, Pradhan S, Carey M (2007) Functional cooperation between HP1 and DNMT1 mediates gene silencing. Genes Dev 21(10):1169-1178

Song CX, Szulwach KE, Fu Y, Dai Q, Yi C, Li X, Li Y, Chen CH, Zhang W, Jian X, Wang J, Zhang L, Looney TJ, Zhang B, Godley LA, Hicks LM, Lahn BT, Jin P, He C (2010) Selective chemical labeling reveals the genome-wide distribution of 5-hydroxymethylcytosine. Nat Biotechnol 29(1):68-72

Song J, Rechkoblit O, Bestor TH, Patel DJ (2011) Structure of DNMT1-DNA complex reveals a role for autoinhibition in maintenance DNA methylation. Science 331(6020):1036-1040

Stadler MB, Murr R, Burger L, Ivanek R, Lienert F, Scholer A, van Nimwegen E, Wirbelauer C, Oakeley EJ, Gaidatzis D, Tiwari
VK, Schübeler D (2011) DNA-binding factors shape the mouse methylome at distal regulatory regions. Nature 480(7378): 490-495

Stroud H, Feng S, Kinney SM, Pradhan S, Jacobsen SE (2011) 5-Hydroxymethylcytosine is associated with enhancers and gene bodies in human embryonic stem cells. Genome Biol 12(6):R5433

Szenker E, Ray-Gallet D, Almouzni G (2011) The double face of the histone variant H33. Cell Res 21(3):421-434

Szulwach KE, Li X, Li Y, Song CX, Wu H, Dai Q, Irier H, Upadhyay AK, Gearing M, Levey AI, Vasanthakumar A, Godley LA, Chang Q, Cheng X, He C, Jin P (2011) 5-hmC-mediated epigenetic dynamics during postnatal neurodevelopment and aging. Nat Neurosci 14(12):1607-1616

Tahiliani M, Koh KP, Shen Y, Pastor WA, Bandukwala H, Brudno Y, Agarwal S, Iyer LM, Liu DR, Aravind L, Rao A (2009) Conversion of 5-methylcytosine to 5-hydroxymethylcytosine in mammalian DNA by MLL partner TET1. Science 324(5929): 930-935

Tolstorukov MY, Goldman JA, Gilbert C, Ogryzko V, Kingston RE, Park PJ (2012) Histone variant H2ABbd is associated with active transcription and mRNA processing in human cells. Mol Cell 47(4):596-607

Valinluck V, Sowers LC (2007) Endogenous cytosine damage products alter the site selectivity of human DNA maintenance methyltransferase DNMT1. Cancer Res 67(3):946-950

Valinluck V, Tsai HH, Rogstad DK, Burdzy A, Bird A, Sowers LC (2004) Oxidative damage to methyl-CpG sequences inhibits the binding of the methyl-CpG binding domain (MBD) of methylCpG binding protein 2 (MeCP2). Nucleic Acids Res 32(14):4100-4108

Vardabasso C, Hasson D, Ratnakumar K, Chung CY, Duarte LF, Bernstein E (2014) Histone variants: emerging players in cancer biology. Cell Mol Life Sci 71(3):379-404

Varriale A (2014) DNA methylation, epigenetics, and evolution in vertebrates: facts and challenges. Int J Evol Biol 475981:7

Vavouri T, Lehner B (2012) Human genes with CpG island promoters have a distinct transcription-associated chromatin organization. Genome Biol 13(11):R110

Vogler C, Huber C, Waldmann T, Ettig R, Braun L, Izzo A, Daujat S, Chassignet I, Lopez-Contreras AJ, Fernandez-Capetillo O, Dundr M, Rippe K, Längst G, Schneider R (2010) Histone H2A C-terminus regulates chromatin dynamics remodeling and histone H1 binding. PLoS Genet 6(12):e1001234

Weber CM, Henikoff S (2014) Histone variants: dynamic punctuation in transcription. Genes Dev 28:672-682

Wiedemann SM, Mildner SN, Bönisch C, Israel L, Maiser A, Matheisl S, Straub T, Merkl R, Leonhardt H, Kremmer E, Schermelleh L, Hake SB (2010) Identification and characterization of two novel primate-specific histone $\mathrm{H} 3$ variants $\mathrm{H} 3 \mathrm{X}$ and H3Y. J Cell Biol 190(5):777-791

Witt O, Albig W, Doenecke D (1996) Testis-specific expression of a novel human H3 histone gene. Exp Cell Res 229(2):301-306

Wu SC, Zhang Y (2010) Active DNA demethylation: many roads lead to Rome. Nat Rev Mol Cell Biol 11(9):607-620

Wu H, D'Alessio AC, Ito S, Wang Z, Cui K, Zhao K, Sun YE, Zhang Y (2011a) Genome-wide analysis of 5-hydroxymethylcytosine distribution reveals its dual function in transcriptional regulation in mouse embryonic stem cells. Genes Dev 25(7):679-684

Wu SS, Xu W, Liu S, Chen B, Wang X, Wang Y, Liu S, Wu J (2011b) Down-regulation of ALKBH2 increases cisplatin sensitivity in H1299. Acta Pharmacol Sin 32(3):393-398

Wyatt GR, Cohen SS (1952) A new pyrimidine base from bacteriophage nucleic acids. Nature 170:1072-1073 
Yang X, Lay F, Han H, Jones PA (2010) Targeting DNA methylation for epigenetic therapy. Trends Pharmacol Sci 31(11):536-546

Yi C, Chen B, Qi B, Zhang W, Jia G, Zhang L, Li CJ, Dinner AR, Yang CG, He C (2012) Duplex interrogation by a direct DNA repair protein in search of base damage. Nat Struct Mol Biol 19(7):671-676
Zhang L, Lu X, Lu J, Liang H, Dai Q, Xu GL, Luo C, Jiang H, He C (2012) Thymine DNA glycosylase specifically recognizes 5-carboxylcytosine-modified DNA. Nat Chem Biol 8:328-330

Zhu JK (2009) Active DNA demethylation mediated by DNA glycosylases. Annu Rev Genet 43:143-166 